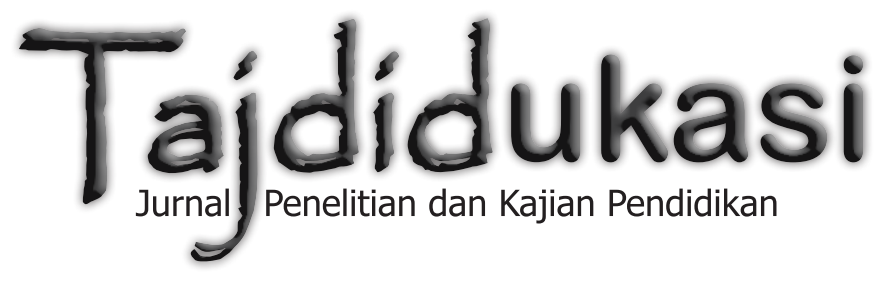




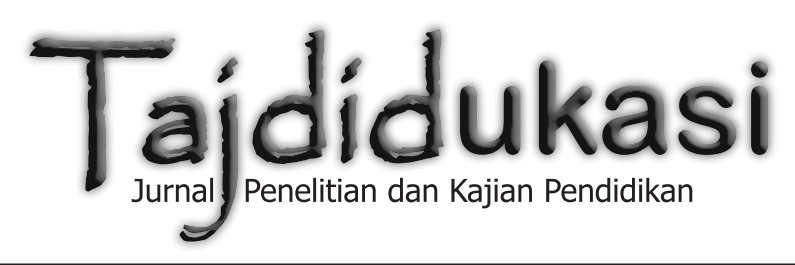

Volume VIII, No. 2, Juli 2018

ISSN: 1979-6943

Tajdidukasi: Jurnal Penelitian dan Kajian Pendidikan merupakan jurnal Penelitian dan Kajian Pendidikan yang berisi Penelitian Tindakan Kelas (PTK) dan Penelitian Tindakan Sekolah (PTS) serta Kajian Pendidikan interdisipliner di Perguruan Tinggi yang diterbitkan Majelis Pendidikan Dasar dan Menengah Pimpinan Wilayah Muhammadiyah Daerah Istimewa Yogyakarta. Artikel hasil PTK dan PTS serta kajian pemikiran pendidikan ditulis oleh para Guru dan Kepala Sekolah serta Dosen dalam mengujicobakan metode dan strategi pembelajaran untuk meningkatkan kualitas pendidikan baik SD/MI, SMP/MTs dan SMA/MA/SMK serta Perguruan Tinggi. Artikel PTK dan PTS fokus pada mata pelajaran di sekolah/madrasah, seperti Ilmu Pengetahuan Alam (IPA), Imu Pengetahuan Sosial (IPS), Matematika, Fisika, Kimia, bahkan teknik, seperti Teknik Mesin, Elektro, Informatika dan lain sebagainya. Sementara itu, artikel Kajian Pendidikan merupakan penelitian interdisipliner dan multidisipliner yang dilakukan Dosen di Perguruan Tinggi terhadap khasanah keIslaman.

Tajdidukasi: Jurnal Penelitian dan Kajian Pendidikan adalah jurnal terbuka yang versi softfile-nya bisa dibaca dan diakses secara gratis, sementara versi print out/ hardcopy dapat diperoleh dengan menghubungi distributor di alamat serial tajdidukasi.ac.id. Sof-file keseluruhan artikel yang diterbitkan dapat diakses melalui Tajdidukasi Open Access Juornal di www.dikdasmenpwmdiy.or.id

Pimpinan Editor
Suyadi, Universitas Ahmad Dahlan (UAD) Yogyakarta, Indonesia

Anggota Editor

Arif Budi Raharjo, Universitas Muhammadiyah Yogyakarta (UMY), Indonesia

Achmad Muhammad, UIN Sunan Kalijaga Yogyakarta, Indonesia

Hendro Widodo, Universitas Ahmad Dahlan (UAD) Yogyakarta

Mundzirin Yusuf, UIN Sunan Kalijaga Yogyakarta, Indonesia

Sumedi, UIN Sunan Kalijaga Yogyakarta, Indonesia

Sukamto, Universitas Muhammadiyah Yogyakarta (UMY), Indonesia

Sumarsono, UIN Sunan Kalijaga Yogyakarta Indonesia

Sarjilah (Lembaga Penjaminan Mutu Pendidikan) Yogyakarta

Fathur Rahman, M.Si., Universitas Negeri Yogyakarta (UNY) Indonesia

\section{Editor Pelaksana}

Suryanto, Universitas Muhammadiyah Yogyakarta (UMY), Indonesia

Suyatno, Universitas Ahmad Dahlan (UAD) Yogyakarta

Farid Setiawan, Universitas Ahmad Dahlan (UAD) Yogyakarta

Alamat Redaksi:

Kantor Majelis Pendidikan Dasar dan Menengah Pimpinan

Wilayah Muhammadiyah D.I. Yogyakarta

J1. Gedongkuning No. 130B Yogyakarta

Kode Pos : 55171

Telephone : (0274) 377078

Facsimile : (0274) 371718

Website : www.dikdasmenpwmdiy.or.id

E-Mail : tajdidukasi@dikdasmenpwmdiy.or.id 


\title{
PENINGKATAN KEDISIPLINAN GURU MELALUI PEMBERIAN REWARD DI SD MUHAMMADIYAH SAPEN YOGYAKARTA
}

\author{
Agung Rahmanto \\ SD Muhammadiyah Sapen Yogyakarta \\ e-mail : agoeng.spn@gmail.com
}

\begin{abstract}
Abstrak
Penelitian ini bertujuan untuk meningkat kedisiplinan guru melalui pemberian reward di SD Muhammadiyah Sapen Yogyakarta. Penelitian ini dilatar belakangi oleh permasalahan terjadinya kondisi kedisiplinan guru dalam hal jam kedatangan yang rendah.

Penelitian ini merupakan Penelitian Tindakan Sekolah (PTS). Subyek penelitian ini adalah guru SD Muhammadiyah Sapen Yogyakarta yang berjumlah 113 orang. Teknik pengumpulan data menggunakan observasi dan dokumentasi. Observasi digunakan untuk mengambil data terkait perilaku guru dalam hal kedisiplinan kehadiran. Dokumentasi digunakan untuk merekam data jam kedatanga guru.

Hasil penelitian menunjukkan bahwa pemberian reward dapat meningkatkan kedisiplinan guru dalam hal jam kedatangan. Pada kondisi awal diperoleh data bahwa guru yang hadir melebihi pukul 06.15 WIB sebanyak $27,8 \%$, atau 72,2\% kehadirannya tepat waktu. Setelah dilakukan siklus pertama dengan memberi reward berupa tambahan insentif kehadiran guru yang melebihi pukul 06.15 WIB menurun menjadi 15, 9\%. Pada akhir siklus pertama artinya terjadi peningkatan kedisiplinan kehadiran guru menjadi $84,1 \%$. Selanjutnya dilakukan siklus kedua yaitu pemberian reward berupa tambahan insentif dan sertifikat karakter, guru yang datang melebihi pukul 06.15 WIB menurun lagi menjadi $2 \%$. Artinya pada akhir siklus kedua, terjadi peningkatan kedisiplinan kehadiran guru menjadi 98\%. Dengan demikian dapat disimpulkan bahwa pemberian reward dapat meningkatkan kedisiplinan guru dalam hal jam kehadiran. Reward yang diberikan tidak cukup hanya tambahan insentif, tetapi perlu disertai sertifikat karakter. Peran sertifikat karakter di sini adalah sebagai pemberi label tentang kedisiplinan guru.
\end{abstract}

Kata Kunci: reward, kedisiplinan, guru

\section{PENDAHULUAN}

Guru merupakan salah satu faktor penentu keberhasilan pelaksanaan pendidikan di sekolah. Hadirnya guru di sekolah akan menjadi tolok ukur kesiapan untuk melaksanakan proses pembelajaran di kelas. semakin awal kehadiran guru di sekolah, maka dapat dilakukan persiapan proses pembelajaran yang waktunya lebih lama. Akan tetapi 
kadang kala kehadiran guru di sekolah tidak seperti yang diharapkan. Beberapa guru hadir tidak di awal waktu, tetapi mendekati batas akhir jam kehadiran yang ditetapkan sekolah.

Sekolah Dasar Muhammadiyah Sapen merupakan salah satu sekolah yang menerapkan disiplin kehadiran guru masksimal pukul 06.20 WIB. Penetapan jam kehadiran ini sudah disosialisikan kepada seluruh warga sekolah. Sekolah selalu menegaskan bahwa guru harus hadir di awal waktu agar persiapan proses pembelajaran dapat dilakukan dalam waktu yang relatif longgar. Akan tetapi ternyata kenyataan tidak seperti yang dihaapkan. Sejauh ini masih ada guru yang hadirnya mendekati batas waktu akhir yaitu pukul 06.20 WIB, sehingga tidak jarang kehadiran siswa lebih jauh mendahului bapak ibu guru di kelas. Kondisi ini jika dikuantitatifkan terdapat lebih dari $25 \%$ guru yang terbiasa hadir mendekati jam 06.20 WIB. Sementara 75\% yang lain kehadirannya jauh sebelum itu, yakni maksimal pukul 06.15 WIB.

Kondisi tersebut tentu tidak dapat dibiarkan berlarut-larut. Pihak sekolah dalam hal ini Kepala Sekolah menghendaki guru untuk hadir di kelas lebih awal dari kehadiran siswanya. Oleh karena itu Kepala Sekolah akan mengambil kebijakan untuk memberlakukan program reward bagi kehadiran guru. Dalam kegiatan ini guru yang hadir lebih awal akan diberikan reward (hadiah). Pemilihan kebijakan pemberian reward ini didasarkan pada teori yang dikemukan Curvin \& Mendler (1999: 52) bahwa konsekuensi adalah bagian penting dari penegakkan aturan. Dalam konteks ini konsekuensi yang diaksud adalah bagi guru yang tertib terhadap jam kedatangan akan memperoleh konsekuensi reward, sementara yang terlambat akan mendapatkan punishment. Di samping itu pendapat lain yang mendukung terkait reward dan punishment dalam penerapan disiplin disampaikan oleh Gottfredsons (dalam Adams, 2000: 153) bahwa untuk menegakkan disiplin sekolah harus mengembangkan dan menerapkan prosedur disiplin yang jelas.

Berdasarkan beberapa pendapat di atas, maka dalam penelitian ini akan digunakan reward untuk meningkatkan disiplin guru di SD Muhammadiyah Sapen Yogyakarta. Disiplin guru yang dimaksud di dalam penelitian ini adalah disiplin terhadap jam kehadiran guru lebih awal, yaitu maksimal pukul 06.15 WIB, tidak mendekati batas akhir dari waktu yang ditentukan sekolah. Indikator keberhasilan dalam penelitian ini dianggap berhasil jika kehadiran guru maksimal 06.15 WIB mencapai 90\%.

\section{Kedisiplinan Guru}

Disiplin merupakan kata yang berasal dari istilah 'disciple' yang dapat diartikan sebagai seseorang yang belajar secara sukarela mengikuti pemimpin. Dalam konteks penelitian ini karena terkait dengan kedisiplinan guru dalam hal jam kehadiran, maka diartikan sebagai tindakan guru untuk mengikuti aturan yang telah ditetapkan pemimpin di sekolah. Pemimpin yang dimaksudkan di 
sini adalah kepala sekolah. Guru yang mengikuti jam kedatangan tentu akan mendapat predikat disiplin, sedangkan yang tidak akan mendapat predikat tidak disiplin.

Dalam Kamus Besar Bahasa Indonesia, Poerwadarminta (2007: 296) mengartikan disiplin sebagai ketaatan pada aturan dan tata tertib. Dari pengertian tersebut dapat diartikan sebagai perilaku mentaati peraturan atau tata tertib. Jika berbicara konteks kedisiplinan guru, maka dapat dimaknai sebagai ketaatan terhadap aturan yang ditentukan sekolah, salah satunya yaitu kedisiplinan dalam hal kehadiran di sekolah. Sebenarnya ketika berbicara tentang ketaatan pada aturan tata tertib guru di sekolah, tidak hanya terbatas pada kehadiran, tetapi meliputi ketaatan terhadap seluruh aturan sekolah yang mencakup kehadiran, tata cara berpakaian, berperilaku, pelaksanaan pembelajaran, administrasi sekolah, dan lain sebagainya.

Berbicara tentang disiplin berhubungan dengan nilai-nilai lain seperti ketekunan, kerja keras, hemat, kemampuan untuk menunda kepuasan, kehatihatian, dan moderasi (Krischenbaum (1995: 22). Lebih lanjut Curvin \& Mindler (1999: 12) ada tiga dimensi disiplin yaitu 1) disiplin untuk mencegah masalah, 2) disiplin untuk memcahkan masalah agar tidak semakin buruk, dan 3) disiplin untuk mengatasi perilaku di luar kontrol.

Berdasarkan pengertian kedisiplinan di atas, dapat disimpulkan bahwa kedisiplinan adalah ketaatan seseorang untuk mengikuti aturan yang berlaku. Aturan di sini adalah kebijakan yang ditentukan oleh penguasa. Dalam konteks sekolah, aturan terkait dengan tata tertib yang harus diikuti guru tentunya berasal dari pemangku kebijakan yaitu Kepala Sekolah.

Guru adalah pendidik profesional dengan tugas utama mendidik, mengajar, membimbing, mengarahkan, melatih, menilai, dan mengevaluasi peserta didik pada pendidikan anak usia dini jalur pendidikan formal, pendidikan dasar, dan pendidikan menengah (Undang-Undang Nomor 14 Tahun 2005 Tentang Guru dan Dosen). Dalam peraturan tersebut juga dijelaskan tentang satuan pendidikan. Satuan pendidikan adalah kelompok layanan pendidikan yang menyelenggarakan pendidikan pada jalur pendidikan formal dalarn setiap jenjang dan jenis pendidikan.

Dengan demikian yang dimaksud dengan disiplin guru adalah etaatan guru untuk mengikuti aturan yang berlaku. Guru di sini adalah pendidika yang ada di dalam satuan pendidikan, termasuk di dalamnya sekolah dasar. Pada dasarnya ada dua tipe kepegawaian di lembaga sekolah, yaitu pendidik dan tenaga non kependidikan. Guru dalam hal ini adalah tenaga yang berpern sebagai pendidik.

Disiplin dalam lingkungan kerja merupakan salah satu hal yang harus diperhatikan. Apabila kedisiplinan dimiliki oleh masing-masing individu dalam lingkungan kerja diharapkan akan dapat membuat suasana kerja menjadi kondusif, sehingga nyaman untuk melakukan 
aktivitas kerja. Hal ini tentunya berlaku juga bagi guru di sekolah.

Kedisiplinan guru di sekolah, salah satunya terkait dengan kehadiran yang sesuai dengan waktu kedatangan yang ditetapkan dalam aturan sekolah. Tanpa adanya kedisiplinan di sebuah lingkungan sekolah akan menyebabkan ketidaknyamanan suasanan kerja di sekolah tersebut. Hal ini senada dengan yang disampaikan oleh Koesoema (2007: 235) bahwa sebuah sekolah tanpa adanya kedisiplinan bak kincir tanpa air. Keberadaan kincir tanpa air tentunya tidak dapat berputar dan menyebabkan gagalnya tujuan diadakannya kincir tersebut. Demikian halnya dengan sekolah, tanpa adanya kedisiplinan, maka sekolah akan terhambat dalam melaksanakan program yang sudah ditetapkan.

Kedisiplinan kehadiran guru akan memberikan dampak positif dimana guru dapat memiliki waktu persiapan pembelajaran yang lebih banyak. Dalam hal ini guru dapat mempersiapkan segala alat dan bahan untuk pembelajaran secara teliti. Di samping itu kehadiran guru di awal waktu juga sangat membuka kesempatan bertemu siswa dan saling menyapa, sehingga siswa merasa nyaman dan siap untuk belajar.

Di samping disiplin guru diperlukan untuk mempersiapkan lingkungan belajar yang kondusif untuk siswa, ternyata disiplin juga mempunyai hubungan yang erat dengan. moral atau semangat kerja pegawai, dalam arti apabila disiplin tinggi, semangat kerjanya pun tinggi, dan sebaliknya apabila disiplin rendah, semangat kerjanya pun biasanya rendah (Ngadiran, 1987:56). Dengan demikian agar semangat kerja guru dalam melaksanakan pembelajaran, sudah seharusnya disiplin kehadirannya juga perlu ditingkatkan.

Kedisiplinan karyawan, atau guru jika di sekolah dipengaruhi oleh banyak faktor untuk mewujudkannya. Faktor yang mempengaruhi tingkat displin karyawan dalam suatu organisasi menurut Hasibuan (Siahaan, 2013) 23) adalah sebagai berikut:
a. Tujuan dan kemampuan.
b. Teladan pimpinan
c. Balas jasa(gaji dan kesejahteraan)
d. Keadilan
e. Pengawasan
f. Sanksi hukum
g. Ketegasan, dan
h. Hubungan kemanusiaan

\section{Reward (Hadiah) dan Punishment (Hukuman)}

Dalam pembentukan kedisiplinan guru ada beberapa unsur yang harus ada. Unsur-unsur disiplin seperti yang dikemukakan oleh (Hurlock, 2002:28) terdiri atas: peraturan sebagai pedoman perilaku, konsistensi dalam peraturan, hukuman untuk pelanggaran, penghargaan untuk perilaku baik. berdasarkan pendapat Hurlock tentang unsur-unsur disiplin tersebut, maka perlu kiranya sekolah menetapkan reward dan $p u$ nishment untuk meningkatkan disiplin kehadiran guru di sekolah.

Reward diartikan oleh Arikunto (1990: 182) sebagai hadiah adalah se- 
suatu yang diberikan kepada orang lain dikarenakan telah menunjukkan tingkah laku sesuai dengan yang dikehendaki. Tingkah laku yang dimaksudkan di sini adalah taat terhadap tata tertib. Reward atau hadiah tidak perlu selalu berupa materi tetapi bisa dalam bentuk pujian, atau penghargaan.

Santrock menjelaskan bahwa penguatan (imbalan) adalah konsekuensi yang meningkatkan probabilitas bahwa suatu perilaku akan terjadi. Penguatan berarti memperkuat, dalam penguatan positif frekuensi respons meningkat karena diikuti dengan stimulus yang mendukung (rewarding), sedang dalam penguatan negatif, frekuensi respons meningkat karena diikuti dengan penghilangan stimulus yang merugikan atau tidak menyenangkan (Azis, 2016: 337).

Dalam upaya meningkatkan kedisiplinan guru terhadap jam kedatangan perlu kiranya diberikan reward bagi yang tertib dan lebih awal datang. Hadiah ini dapat berupa materi atau penghargaan lain yang mengandung makna di dalamnya. Wujud penghargaan ini misalnya dana pembinaan, sertifikat, pujian atau penghormatan.

Penelitian yang dilakukan oleh Siahaan (2013: 26) menemukan bahwa reward dan punishment akan berpengaruh signifikan terhadap disiplin kerja pegawai. Reward dan punishment dapat merangsang kedisiplinan kerja karyawan. Adanya reward dan punishment, karyawan merasa dapat perhatian, bimbingan, petunjuk, pengarahan diri atasannya, sehingga dengan sendirinya karyawan berusaha untuk memberikan yang terbaik kepada perusahaan tempatnya bekerja.

Reward bentuknya sangat beragam. Hadiah atau reward yang diberikan kepada pegawai untuk memotivasi kierja dapat berupa bonus, promosi, penambahan tanggung jawab. Khusus yang terakhir bisa memiliki dampak sebagai beban ataupun menjadi poin bagi sang pegawai tersebut (Siahaan, 2013: 21). Winardi (Siahaan, 2013:21) memerinci macam-macam reward ke dalam bentuk sebagai berikut:

a. Material berupa gaji/upah.

b. Imbalan diluar gaji, dapat berupa istrahat kerja, dan bonus.

c. Penghargaan sosial, dapat berupa reward informal, yaitu pujian, senyum, umpan balik evaluatif, isyarat - isyarat nonverbal, tepukan dibahu, meminta saran, undangan minum kopi bersama atau makan bersama, penghargaan formal, dan plakat dinding.

d. Tugas itu sendiri, seperti perasaan berprestasi, pekerjaan dengan tanggung jawab lebih besar rotasi kerja, dan sebagainya.

e. Diterapkan sendiri, yaitu berupa reward terhadap diri sendiri, pujian untuk diri sendiri, ucapan selamat untuk diri sendiri.

Apabila kita bicara reward atau hadiah, maka erat kaitannya dengan hukuman. Thorndike berpendapat bahwa hukuman adalah memaksakan dampaknya atas perilaku dengan melemahkan hubungan antara stimulus. Hukuman 
merupakan bentuk konsekuensi yang kurang menyenangkan untuk suatu respon perilaku tertentu atau meghilangkan suatu bentuk penguat yang diinginkan karena respon perilaku tertentu (Ardini, 2015: 253). Berdasarkan pendapat tersebut, maka jika dikaitkan dengan upaya meningkatkan kedisiplinan kehadiran guru hukuman perlu dilakukan sebagai respon terhadap perilaku ketidak disiplinan guru. Artinya hukuman perlu diberikan bagi guru yang tidak disiplin dalam hal jam kedatangan.

Skinner (Azis, 2016: 334) menjelaskan bahwa hukuman diberikan atas alasan sebagai berikut:

a. Hukuman dapat menimbulkan efek emosional yang tidak diharapkan.

b. Hukuman hanya dapat memberi tahu apa yang tidak boleh dilakukan, bukan yang harus dilakukan.

c. Hukuman seolah-olah membenarkan tindakan menyakiti orang lain.

d. Hukuman dalam situasi tertentu, seharusnya dilakukan hukuman.

e. Hukuman sering menghilangkan perilaku yang tidak diinginkan atau muncul perilaku lain yang tidak kehendaki pula.

\section{Hipotesis Tindakan}

Reward dapat meningkatkan kedisiplinan kehadiran guru di SD Muhammadiyah Sapen Yogyakarta.

\section{Metode Penelitian}

1. Lokasi, Ruang Lingkup, dan Subyek Penelitian
Penelitian ini dilaksanakan di SD Muhammadiyah Sapen Kota Yogyakarta. Ruang lingkup penelitian ini adalah kedisiplinan kehadiran guru. Pengukuran kedisiplinan kehadiran guru didasarkan pada jam kedatangan yang ditetapkan sekolah, yaitu 06.15 WIB. Subyek penelitiannya adalah guru SD Muhammadiyah Sapen Yogyakarta yang berjumlah 113 orang.

\section{Desain Penelitian}

Penelitian ini merupakan Penelitian Tindakan Sekolah (PTS) yang dilakukan oleh Kepala Sekolah SD Muhammadiyah Sapen Kota Yogyakarta. Penelitian ini dilaksanakan dalam beberapa siklus. Masing-masing siklus terdiri dari tahap perencanaan, tindakan, pengamatan, dan refleksi.

\section{a. Perencanaan}

Pada tahap perencanaan, kepala sekolah melakukan penyusunan instrumen penelitian berupa lembar pencatatan kehadiran guru di sekolah, dan lembar field notes untuk mendeskripsikan perilaku guru di pagi hari. Peneliti juga merencanakan tentang bentuk reward, serta waktu pemberiannya.

\section{b. Tindakan}

Pada tahap tindakan ini peneliti melakukan sosialisasi kepada seluruh guru tentang peraturan kehadiran maksimal pukul 06.15 WIB.

\section{c. Pengamatan}

Tahap pengamatan digunakan peneliti untuk mengamati aktivitas guru di pagi hari, terutama pada kedisiplinan 
Agung Rahmanto - Peningkatan Kedisiplinan Guru Melalui Pemberian Reward di SD Muhammadiyah....

terhadap jam kedatangan. Pada tahap ini kehadiran guru direkan dalam lembat pencatatan jam kehadiran guru. Pencatatan dilakukan selama 1 minggu berturut-turut. Selanjutnya bagi guru yang selalu hadir maksimal pukul 06.15 WIB akan mendapatkan reward berupa sertifikat penghargaan sebagai guru yang paling rajin hadir. Pemberian sertifikat penghargaan ini bertujuan untuk mengapresiasi kedisiplinan guru.

\section{d. Refleksi}

Pada tahap refleksi digunakan oleh peneliti untuk melihat peningkatan kehadiran guru lebih awal dari pukul 06.20 WIB, yaitu pukul 06.10 WIB. Apabila indikator keberhasilan belum dicapai, maka akan dilakukan siklus berikutnya.

\section{Teknik Pengumpulan Data}

Pengumpulan data dilakukan dengan teknik wawancara, observasi, dan dokumentasi. Wawancara dilakukan dengan informan guru terkait dengan respon terhadap reward yang diberikan pihak sekolah. Observasi digunakan untuk megambil data terkait dengan perilaku kedatangan guru di sekolah. Dokumentasi dilakukan untuk memperoleh data terkait dengan rekaman data jam kehadiran guru di sekolah.

\section{Teknik Analisis Data}

Analisis data dilakukan secara deskriptif. Data akan disajikan dengan cara memaparkan hasil wawancara terkait dengan proses pemberian reward untuk guru. Analisis data dilakukan juga untuk data dokumentasi hasil rekap jam kehadiran guru di sekolah.

\section{HASIL DAN PEMBAHASAN}

\section{Hasil Penelitian}

a. Hasil Penelitian Pra Tindakan

Berdasarkan hasil data pra tindakan menunjukkan bahwa tingkat kehadiran guru yang maksimal pukul 06.15 WIB sebanyak $72,2 \%$. Data tersebut menunjukkan bahwa masih terdapat sebanyak $27,8 \%$ guru yang kehadirannya melebihi pukul 06.15 WIB. Hadirnya guru yang melebihi pukul 06.15 WIB ini menyebabkan waktu yang tersedia untuk melakukan persiapan pembaelajaran di kelas menjadi lebih pendek. Kehadiran guru yang melebihi pukul 06.15 WIB juga terkadang menimbulkan masalah adanya siswa yang hadir di kelas, tetapi tidak memperoleh pengawasan dari guru kelas.

Sebagai pihak yang memegang kebijakan di SD Muhammadiyah Sapen, Kepala Sekolah mengambil kebijakan untuk meminimalisir kehadiran guru lebih dari pukul 06.15 WIB. Guna meningkatkan kedisiplinan guru dalam hal jam kehadiran, Kepala Sekolah mengambil kebijakan untuk menerapkan sistem reward bagi guru-guru, dimana indikatornya salah satunya terkait dengan kedisiplinannya dalam hal kehadiran.

b. Siklus 1

\section{1) Perencanaan}

Setelah melihat data awal pra siklus, peneliti menyusun rencana tindakan di siklus pertama. Tujuan tindakan di siklus pertama ini meningkatkan kedi- 
siplinan guru dalam hal jam kedatangan. Tindakan yang akan dilaksanakan adalah pemberian reward kepada guru yang kedatangannya selalu awal. Perlakuan ini direncanakan akan diberikan pada waktu setelah diamati kedatangan guru selama satu minggu. Program ini disosialisasikan kepada seluruh guru dan karyawan. Sekolah akan mengambil kebijakan memilih lima orang yang kedatangannya selalu awal. Pemberian reward direncanakan dalam bentuk hadiah berupa uang di luar gaji. Pelaksanaan pemberian reward dilakukan di hari Rabu saat pembinaan gru dan karyawan. Pada siklus pertama peneliti mempersiapkan perangkat untuk mencatat jam kehadiran guru.

\section{2) Pelaksanaan Tindakan}

Setelah dilakukannya perencanaan, kemudian dilakukan tindakan pemberian reward untuk meningkatkan kedisiplinan guru dalam hal kehadiran. Pada siklus ini perlakuan yang dilakukan adalah memberikan reward bagi lima orang guru yang kehadirannya selalu sebelum pukul 06.15 WIB. Kegiatan ini dilaksanakan dengan cara merangking jam kehadiran guru melalui dokumen rekaman jam kehadiran guru.

Reward yang diberikan di siklus pertama ini berupa tambahan insentif bagi pegawai yang terpilih sebagai lima terdisiplin. Pemberian intensif ini dimaksudkan untuk mendorong pegawai menjadi lebih tertib terutama dalam hal jam kehadiran. Harapannya dengan pemberian insentif akan menja- di motivator bagi pegawai yang memperolehnya, dan mendorong yang lain untuk berlomba memperoleh reward yang sama dengan memperbaiki jam kehadiran.

\section{3) Observasi}

Setelah dilakukan pemberian reward bagi pegawai yang jam kehadirannya maksimal pukul 06.15 WIB diadakan observasi terhadap perilaku kehadiran pegawai. Berdasarkan hasil observasi pada siklus pertama ini kehadiran pegawai yang tidak lebih dari pukul 06.15 WIB sebanyak 84,1\%. Adapun pegawai yang kehadirannya melebihi pukul 06.15 WIB sebanyak $15,9 \%$. Meskipun belum mencapai indikator keberhasilan yaitu $90 \%$, tetapi setelah dilakukan siklus pertama ini kedisiplinan jam kehadiran pegawai sudah mengalami peningkatan jika dibandingkan dari keadaan awal.

\section{4) Refleksi}

Berdasarkan hasil perlakuan pada siklus pertama, maka peneliti melakukan refleksi. Berdasarkan refleksi yang dilakukan peneliti maka pada siklus pertama ini indikator keberhasilan yang ditetapkan sebanyak $90 \%$ guru yang hadir maksimal pukul 06.15 WIB belum tercapai. Reward berupa materi yang diwujudkan dalam bentuk intensif tambahan belum sepenuhnya mampu mendorong guru untuk lebih tertib dalam jam kehadiran.

Setelah refleksi dilakukan, peneliti menyimpulkan bahwa perlu dilakukan siklus kedua. Dalam siklus kedua ini 
peneliti merencanakan untuk menambah jenis reward yang diberikan. Pada siklus kedua reward yang diberikan tidak hanya hanya berupa insentif tetapi juga sertifikat karakter yang mencerminkan perilaku guru terutama dalam hal kedisiplinan jam kehadiran. Hadiah insentif tetap diberikan di siklus kedua, didampingi dengan sertifikat karakter.

c. Siklus 2

5) Perencanaan

Seperti halnya siklus pertama, pada siklus kedua ini peneliti melakukan perencanaan tindakan. Dalam tahap perencanaan yang dilakukan peneliti adalah merencanakan waktu pemberian reward dan sertifikat kepada guru yang disiplin dalam hal kehadiran. Direncanakan akan dipilih 5 orang guru yang jam kehadirannya paling tertib. Pemberian reward dan sertifikat ini diberikan pada saat kegiatan pembinaan guru. Pada siklus kedua ini peneliti juga mempersiapkan perangkat untuk merekam jam kehadiran guru seperti halnya pada siklus pertama.

\section{6) Pelaksanaan Tindakan}

Pelaksanaan tindakan di siklus pertama diawali dengan sosialisasi program pemberian sertifikat dan reward berupa insentif kepada guru yang jam kehadirannya tidak lebih dari pukul 06.15 WIB. Pemberian sertifikat dimaksudkan agar menjadi label positif bagi guru yang hadir sebelum pukul 06.15 WIB.

Setelah dilakukan sosialisasi dan diberikan treatment berupa pemberian insentif dan sertifikat bagi guru yang jam kehadirannya paling disiplin, selanjutnya dilakukan perekaman kehadiran guru menggunakan perangkat yang telah dipersiapkan. Seperti pada siklus sebelumnya peneliti mencatat satu per satu jam kehadiran guru sesuai dengan yang telah direncanakan. Pencatatan dilakukan dengan tertib terhadap satu per satu guru. Pencatatan kehadiran ini dilakukan tiap hari selama satu minggu.

Pelaksanaan kegiatan pemberian reward di siklus ke dua ini dibuktikan dengan dukungan data foto proses pemberian reward berupa tambahan insentif dan uang pembinaan sebagai berikut.

\section{7) Observasi}

Pada siklus ke dua observasi terhadap perilaku guru dalam hal kedisiplinan jam kehadiran setelah dilakukan tindakan pemberian reward berupa sertifikat dan uang tambahan insentif. Setelah dilakukan obserbasi terhadap perilaku kehadiran guru dapat disimpulkan bahwa jumlah guru yang hadir melebihi pukul 06.15 WIB mengalami penurunan. Berdasarkan pencatatan diperoleh data bahwa guru yang hadir maksimal pukul $06.15 \%$ sebanyak $98 \%$. Adapun $2 \%$ guru yang lain masih lebih dari pukul 06.15 WIB kehadirannya.

\section{8) Refleksi}

Dalam siklus kedua ini peneliti juga melakukan refleksi. Pada siklus kedua berdarakan data observasi dan pencatatan jam kehadiran guru, maka dapat disimpulkan bahwa kehadiran guru 
yang melebihi jam 06.15 WIB jumlahnya sangat sedikit, yaitu $2 \%$. Adapun 98\% guru sudah hadir maksimal pukul 06.15. WIB. Dengan demikian dapat disimpulkan bahwa indikator keberhasilan telah tercapai pada siklus ke dua. Dikarenakan indikator keberhasilan yang ditetapkan peneliti yaitu guru hadir maksimal pukul 06.15 WIB sebanyak $90 \%$ sudah tercapai, maka peneliti menghentikan tindakan di siklus ke dua ini, dan penelitian diangapselesai.

\section{Pembahasan}

Berdasarkan data hasil penelitian yang dilakukan, maka dapat disimpulkan bahwa pemberian reward dapat meningkatkan kedisiplinan guru dalam hal kehadiran. Data hasil penelitian menunjukkan bahwa sebelum dilakukan tindakan jam kehadiran guru yang melebihi pukul 06.15 WIB sebanyak $27,8 \%$. Kondisi ini mendorong peneliti untuk melakukan tindakan berupa pemberian insentif tambahan bagi guru yang hadir maksimal pukul 06.15 WIB. Peneliti melakukan tindakan siklus 1 dengan memberikan insentif berupaka uang dan hasilnya kedisiplinan kehadiran guru menunjukkan kemajuan yaitu guru yang hadir melebihi pukul 06.15 WIB mengalami penurunan yaitu $15,9 \%$. Dikarenakan indikator keberhasilan yang ditetapkan peneliti belum tercapai, maka dilakukan tindakan siklus kedua yaitu pemberian reward berupa uang insentif tambahan dan sertifikat karakter. Dengan tindakan yang dilakukan di siklus kedua ini ternyata kehadiran guru yang melebihi pukul
06.15 WIB mengalami penurunan sangat signifikan, yaitu hanya sebesar $2 \%$. Adapun $98 \%$ yang lain hadir maksimal pukul 06.15 WIB. Dengan demikian indikator yang ditetapkan peneliti sebesar $90 \%$ sudah tercapai.

Kedisiplinan kehadiran guru merupakan salah satu hal yang memiliki dampak positif dimana guru dapat memiliki waktu persiapan pembelajaran yang lebih banyak. Guru yang hadir lebih awal di sekolah dapat mempersiapkan segala alat dan bahan untuk pembelajaran secara teliti. Keculai itu kehadiran guru di awal waktu juga sangat membuka kesempatan bertemu siswa dan saling menyapa, sehingga siswa merasa nyaman dan siap untuk belajar. Oleh karena itu kedisiplinan kehadiran guru perlu ditegaskan agar dapat mempersiapkan kelas sebagai lingkungan yang kondusif untuk siswa belajar.

Di samping disiplin guru diperlukan untuk mempersiapkan lingkungan belajar yang kondusif untuk siswa, ternyata disiplin juga mempunyai hubungan yang erat dengan. moral atau semangat kerja pegawai, dalam arti apabila disiplin tinggi, semangat kerjanya pun tinggi, dan sebaliknya apabila disiplin rendah, semangat kerjanya pun biasanya rendah (Ngadiran, 1987:56). Hal ini tentunya akan berdampak ppada semangat guru dalam melaksanakan tugasnya sebagai pendidik. Oleh karena itu agar semangat kerja guru dalam melaksanakan pembelajaran, sudah seharusnya disiplin kehadirannya juga perlu ditingkatkan.

Pendapat lain menjelaskan bahwa, 
kedisiplinan karyawan, atau guru jika di sekolah dipengaruhi oleh banyak faktor untuk mewujudkannya. Faktor yang mempengaruhi tingkat displin karyawan dalam suatu organisasi menurut Hasibuan (Siahaan, 2013) 23) adalah sebagai berikut:
a. Tujuan dan kemampuan.
b. Teladan pimpinan
c. Balas jasa(gaji dan kesejahteraan)
d. Keadilan
e. Pengawasan
f. Sanksi hukum
g. Ketegasan, dan
h. Hubungan kemanusiaan

Jika dilihat dari teladan kepala sekolah di SD Muhammadiyah Sapen Yogyakarta, bahwa kedua kepala sekolah sudah memberikan teladan yang baik dalam hal kedisiplinan jam kehadiran. Akan tetapi ternyata ada guru yang tidak disiplin dalam hal jam kehadiran. Hal inilah yang melatarbelakangi kepala sekolah melakukan penelitian tindakan sekolah untuk memperbaiki jam kehadiran guru. Kepala sekolah dalam hal ini memilih tindakan untuk memberikan reward kepada guru yang selalu hadir sebelum pukul 06.15 WIB. Pemberian reward yang dipilih berupa insentif tambahan. Reward ini didasarkan pada alasan bahwa salah satu faktor yang mempengaruhi kedisiplinan pegawai adalah balas jasa atau gaji yang diberikan institusi.

Berdasarkan konsep reward bentuknya sangat beragam. Hadiah atau reward yang diberikan kepada pegawai untuk memotivasi kierja dapat berupa bonus, promosi, penambahan tanggung jawab. Khusus yang terakhir bisa memiliki dampak sebagai beban ataupun menjadi poin bagi sang pegawai tersebut (Siahaan, 2013: 21).

Winardi (Siahaan, 2013: 21) memerinci macam-macam reward ke dalam bentuk sebagai berikut:

a. Material berupa gaji/upah.

b. Imbalan diluar gaji, dapat berupa istrahat kerja, dan bonus.

c. Penghargaan sosial, dapat berupa reward informal, yaitu pujian, senyum, umpan balik evaluatif, isyarat - isyarat nonverbal, tepukan dibahu, meminta saran, undangan minum kopi bersama atau makan bersama, penghargaan formal, dan plakat dinding.

d. Tugas itu sendiri, seperti perasaan berprestasi, pekerjaan dengan tanggung jawab lebih besar rotasi kerja, dan sebagainya.

Atas dasar pertimbangan pendapat di atas, maka peneliti melakukan tindakan berupa pemberian reward untuk meningkatkan kedisiplinan guru dalam hal jam kehadiran. Setelah dilakukan tindakan ternyata hipotesis tindakan yang dibuat peneliti terbukti, bahwa reward dapat meningkatkan kedisiplinan guru dalam hal kehadiran.

\section{PENUTUP}

1. Kesimpulan

Berdasarkan hasil penelitian yang dilaksanakan dapat disimpulkan bahwa pemberian reward dapat meningkatkan 
kedisiplinan guru di SD Muhammadiyah Sapen Yogykarta. Kedisiplinan guru dalam hal ini diukur dengan indikator kedisiplinan dalam hal kehadiran. Penelitian ini dilakukan dalam dua siklus, dimana siklus pertama dilakukan dengan reward yang diberikan berupa tambahan insentif bagi guru yang kedisisplinannya tinggi. Perlakuan ini ternyata belum dapat mencapai indikator keberhasilan yang ditetapkan, sehingga dilakukan siklus kedua. Pada siklus kedua di samping memberikan reward berupa tambahan insentif, juga diberikan reward berupa sertifikat penghargaan. Melalui reward ini indikator keberhasilan yang ditetapkan dapat tercapai.

\section{Saran}

Berdasarkan temuan penelitian, dalam penelitian ini dapat disampaikan saran bahwa pemberian reward untuk meningkatkan kedisiplinan guru tidak cukup berupa materi, tetapi perlu penghargaan berupa sertifikat sebagai label perilaku disiplin guru.

\section{DAFTAR PUSTAKA}

Adams, A.T. 2000. The status of school discipline and violence. The $A N$ NALS of the American Academy of Political and Social Science, 567, hlm. 139-146
Ardini. 2015. "Penerapan Hukuman", Bias Antara Upaya Menanamkan Disiplin Dengan Melakukan Kekerasan Terhadap Anak. Jurnal Pendidikan Anak Usia Dini. Vo. 9, No. 2, pp. 251-266

Azis. 2016. Reward-Punishment Sebagai Motivasi Pendidikan (Perspektif Barat Dan Islam). Cendekia Vol. (14), No. (2), pp. 334-349

Curvin, R. L., \& Mendler, A. N. 1999. Discipline with dignity. USA: Association for Supervision and Curriculum Development.

Hurlock, E. 2002. Tahap Perkembangan. Jakarta: Erlangga.

Kesuma, D. dkk. (2011). Pendidikan Karakter : Kajian Teori dan Praktik di Sekolah. Bandung: Remaja Rosdakarya.

Ngadiran. 1987. Menumbuhkan Rasa Disiplin Pegawai. Cakrawala Pendidikan. Vol. (1), No. (6), pp. 56-67.

Siahaan, R. 2013. Pengaruh Reward Dan Punishment Terhadap Disiplin Kerja Karyawan Pada PT. Perkebunan Nusantara III Rambutan. Jurnal Ilmiah Bussiness Progress. Vol (1), No. (1). pp. 17-26. 